\title{
Differentiation between Xanthomonas campestris pv. oryzae, Xanthomonas campestris pv. oryzicola and the Bacterial 'Brown Blotch' Pathogen on Rice by Numerical Analysis of Phenotypic Features and Protein Gel Electrophoregrams
}

\author{
By C. M. VERA CRUZ,'F. GOSSELE, ${ }^{2} \mathrm{~K}$. KERSTERS, ${ }^{2 *}$ P. SEGERS, ${ }^{2}$ \\ M. VAN DEN MOOTER, ${ }^{2}$ J. SWINGS ${ }^{2}$ AND J. DE LEY ${ }^{2}$ \\ ${ }^{1}$ International Rice Research Institute, Los Baños, Laguna, Philippines \\ ${ }^{2}$ Laboratorium voor Microbiologie en microbiële Genetica, Rijksuniversiteit, Ledeganckstraat 35. \\ B-9000 Gent, Belgium
}

(Received IS May 1984)

Thirty-five Xanthomonas campestris pv. oryzae, fourteen $X$. campestris pv. oryzicola strains and six 'brown blotch' pathogens of rice, all of different geographical origin, were studied by numerical analysis of 133 phenotypic features and gel electrophoregrams of soluble proteins, $\% \mathrm{G}+\mathrm{C}$ determinations and DNA :rRNA hybridizations. The following conclusions were drawn. (i) The Xanthomonas campestris pathovars oryzae and oryzicola display clearly distinct protein patterns on polyacrylamide gels and can be differentiated from each other by four phenotypic tests. (ii) Both pathovars are indeed members of Xanthomonas which belongs to a separate rRNA branch of the second rRNA superfamily together with the rRNA branches of Pseudomonas fluorescens, Marinomonas, Azotobacter, Azomonas and Frateuria. (iii) 'Brown blotch' strains are considerably different from $X$. campestris pv. oryzae and oryzicola. They are not members of the genus Xanthomonas, but are more related to the generically misnamed Flavobacterium capsulatum, Pseudomonas paucimobilis, Flavobacterium devorans and 'Pseudomonas azotocolligans' belonging in the fourth rRNA superfamily. (iv) No correlation was found between the virulence, pathogenic groups or geographical distribution of $X$. campestris pv. oryzae or pv. oryzicola strains and any phenotypic or protein electrophoretic property or clustering.

\section{INTRODUCTION}

Bacterial blight of rice, caused by Xanthomonas campestris pv. oryzae (Ishiyama 1922) Dye 1978, is a major problem for the cultivation of rice in Asia (Ou, 1972). The disease has also been reported in Northern Australia (Aldrick et al., 1973), Latin America (Lozano, 1977) and Africa (Buddenhagen et al., 1979; Reckhaus, 1983). Present knowledge on the symptomatology, epidemiology and control of the disease, as well as the morphology, cytology, physiology, toxin production, host range, serology, pathogenic variability and phage sensitivity of its causal agent have been reviewed (Mizukami \& Wakimoto, 1969; Anonymous, 1970; Ou, 1972). Several authors have tried to classify $X$. campestris pv. oryzae strains on the basis of their phage sensitivity (Wakimoto, 1960), serological properties (Choi et al., 1980), phenotypic features (Shekhawat \& Srivastava, 1968; Hifni et al., 1975; Reddy \& Ou, 1976; Tsuchiya et al., 1982a) and pathogenic variability (Ezuka \& Sakaguchi, 1978; Mew \& Vera Cruz, 1979). Serovar specificity of the strains is highly correlated with their phage sensitivity (Tsuchiya et al., 1982b). However, no correlation was found between the pathogenic variability and any of the phenotypic features of the strains (Hifni et al., 1975; Tsuchiya et al., 1982a).

Leaf streak, caused by $X$. campestris pv. oryzicola (Fang et al., 1957) Dye 1978, is another economically important rice disease widespread in tropical Asia. It has not been reported from Japan or other temperate regions (Ou, 1972). 
Lozano et al. (1981) reported the occurrence of a new bacterial rice disease in Central and Latin America, designated as 'brown blotch'. The pathogen was assigned to the genus $X a n t h o m o n a s$ but a subgeneric identification was not provided.

The disease patterns caused by the three pathogens are well defined and can be differentiated easily from each other. In the seedbed, $X$. campestris pv. oryzae causes tiny water-soaked spots at the margins of fully developed leaves. These spots enlarge and turn yellow, and the plant finally dries and wilts. In the case of adult plants, lesions are first observed at the margin near the tip as water-soaked strips which have a waxy margin, enlarge, turn yellow and finally cover the entire leaf, which becomes greyish due to saprophytic growth (Ou, 1972). Bacterial leaf streak is characterized initially by fine translucent streaks along the leaves, over the larger veins. Later, the lesions turn brown, spreading over the entire leaf, which dies $(\mathrm{Ou}, 1972)$. The symptoms of 'brown blotch' disease comprise the spreading and enlargement of brown blotches on the leaves (Lozano et al., 1981).

Bacterial rice pathogens have been studied mostly from a phytopathological point of view. Bacteriological studies on $X$. campestris pv. oryzae and pv. oryzicola have been published by $\mathrm{Mu}$ koo \& Isaka (1964), Goto (1964), Watanabe (1966), Shekhawat \& Srivastava (1968), Reddy \& Ou (1974, 1976), Hifni et al. (1975) and Tsuchiya et al. (1982a). An extensive comparative taxonomic study has not been carried out up to now.

The objectives of the present study were: (1) to determine the degree of phenotypic similarity of $35 X$. campestris pv. oryzae, $14 X$. campestris pv. oryzicola strains and 6 'brown blotch' isolates of different geographical origin by numerical analysis of 133 phenotypic features; (2) to determine the fine internal structure of these taxa by numerical analysis of polyacrylamide gel electrophoregrams; (3) to determine the generic affiliation of the unnamed 'brown blotch' isolates by DNA :rRNA hybridizations; (4) to construct a diagnostic key for the differentiation of $X$. campestris pv. oryzae, $X$. campestris pv. oryzicola and the 'brown blotch' isolates from each other; (5) to verify whether there is any correlation between the virulence of the strains and some of their phenotypic or protein electrophoretic properties.

\section{METHODS}

Organisms used. The strains (Table 1) were grown at $28^{\circ} \mathrm{C}$ on GYCA medium, consisting of $1 \%(w / v)$ b-glucose, $0.5 \%(w / v)$ yeast extract (Oxoid), $3 \%(w / v) \mathrm{CaCO}_{3}$ and $2.5 \%(w / v)$ agar in tap water (modified from Dye, 1962). They were maintained at $4^{\circ} \mathrm{C}$ on the same medium. The cultures used for the phytopathological tests on rice variety TNI were grown on Wakimoto's potato semi-synthetic medium containing $300 \mathrm{~g}$ potato, $0.5 \mathrm{~g}$ $\mathrm{Ca}\left(\mathrm{NO}_{3}\right)_{2}, 4 \mathrm{H}_{2} \mathrm{O}, 2 \mathrm{~g} \mathrm{Na} 2 \mathrm{HPO}_{4} \cdot 12 \mathrm{H}_{2} \mathrm{O}, 5 \mathrm{~g}$ peptone, $20 \mathrm{~g}$ sucrose and $15 \mathrm{~g}$ agar in 1 litre of distilled water $(\mathrm{Ou}$, 1972).

Morphological, physiological and biochemical features. Gram-staining was performed on cells grown for $48 \mathrm{~h}$ on GYCA medium. Two basal media were used: (1) YS medium containing $0.05 \%(w / v) \mathrm{NH}_{4} \mathrm{H}_{2} \mathrm{PO}_{4}, 0.05 \%(\mathrm{w} / \mathrm{v})$ $\mathrm{K}_{3} \mathrm{HPO}_{4}, 0.02 \%(\mathrm{w} / \mathrm{v}) \mathrm{MgSO}_{4} .7 \mathrm{H}_{2} \mathrm{O}, 0.5 \%(\mathrm{w} / \mathrm{v}) \mathrm{NaCl}$ and $0.5 \%$ yeast extract (Oxoid) in distilled water (Dye, 1962) and (2) GYEA medium containing 0.5\% D-glucose, $0.1 \%$ yeast extract (Oxoid), a trace of $\mathrm{FePO}_{4}$ and $2 \%$ agar (Dickinson et al., 1975). Indole production was detected after $5 \mathrm{~d}$ by Kovacs' (1928) reagent in a medium containing $0.5 \%$ yeast extract and $2 \%(w / v)$ tryptone (Oxoid) (Dye, 1962: modified). Acetoin formation was observed in YS medium supplemented with $0.5 \%$ D-glucose, after $5 \mathrm{~d}$, using Barritt's (1936) reagent. Urease activity was tested according to Dye (1962). Gelatinase activity was detected in GYEA medium in tubes with $2 \%$ agar replaced by $12 \%(w / v)$ gelatine. The tubes were stab-inoculated and the results were observed after $14 \mathrm{~d}$. Reactions in litmus milk, i.e. strong peptonization, alkalinization and reduction, were observed after $14 \mathrm{~d}$ incubation. Starch hydrolysis was detected by streaking a loopful of cells on a medium containing $0.5 \%(w / v)$ neutralized peptone (Oxoid), $0.3 \%$ yeast extract, $0.2 \%(\mathrm{w} / \mathrm{v})$ soluble starch and $2 \%$ agar in distilled water. Lugol's iodine solution was poured on the plates after $7 \mathrm{~d}$ incubation. For the aesculin and arbutin hydrolysis tests, a medium consisting of GYEA supplemented with $0.05 \%(w / v)$ ferric ammonium citrate and either $0.3 \%(w / v)$ aesculin or $0.3 \%(w / v)$ arbutin, respectively, was inoculated by streaking a loopful of cells on the medium. A black zone (in visible light) and a clear zone (in UV light) around the growth streak indicated a positive reaction. Pectinase activity was tested using Beraha's (1968) procedure after $14 \mathrm{~d}$ incubation. The production of 2-ketogluconic acid by resting cells in a $2 \%(w / v)$ sodium gluconate solution in $0.01 \mathrm{M}$-phosphate buffer, $\mathrm{pH} 7 \cdot 0$, was detected after $7 \mathrm{~d}$ incubation in a shaking apparatus by thin-layer chromatography using o-phenylenediamine hydrochloride as spray reagent. This reagent yields a blue fluorescent colour with 2-ketogluconic acid upon observation of the chromatograms under UV light $16 \mathrm{~h}$ after spraying (Gosselé et al., 1980). Phenylalanine deaminase activity was detected on slants con- 
sisting of $0.3 \%$ yeast extract, $0.1 \%(w / v) \mathrm{Na}_{2} \mathrm{HPO}_{4} .0 .5 \% \mathrm{NaCl}$ and $2 \%$ agar; $\mathrm{L}$-phenylalanine was added separately to a final concentration of $0.1 \%(w / v)$. After $7 \mathrm{~d}$ incubation, $10 \%(w / v) \mathrm{FeCl}_{3}$ solution was added and the development of a green colour indicated the presence of phenylpyruvate (Ewing et al., 1957). We used the method of Dye (1962) for testing the tyrosinase activity after $14 \mathrm{~d}$ incubation in a shaking apparatus. The production of $\mathrm{H}_{2} \mathrm{~S}$ from L-cysteine or peptone was detected with lead(II) acetate paper strips in YS medium (NaCl omitted) containing $0.01 \%(w / v)$ cysteine or $0.02 \%$ peptone, respectively. Hydrolysis of Tween $20,40,60$ and 80 was observed after $4 \mathrm{~d}$ incubation on a medium consisting of $1 \%$ peptone (Difco), $0.01 \%(\mathrm{w} / \mathrm{v}) \mathrm{CaCl}_{2}, 2 \mathrm{H}_{2} \mathrm{O}, 0.1 \%$ yeast extract and $2 \%$ agar with the Tweens added separately to a final concentration of $1 \%(\mathrm{v} / \mathrm{v})$. Egg yolk hydrolysis was checked on GYEA medium supplemented with $1 \% \mathrm{NaCl}$ and $10 \%(\mathrm{v} / \mathrm{v})$ egg yolk solution (Oxoid). Kovacs' (1956) reagent was used for the oxidase test. Reduction of $0.001 \%(w / v) \mathrm{K}_{2} \mathrm{TeO}_{3}$ in GYEA was indicated by a blackening of the medium. The oxidation-fermentation (O/F) test was performed by stab-inoculation in a medium containing $0.2 \%$ peptone, $0.5 \% \mathrm{NaCl}, 0.03 \% \mathrm{~K}_{2} \mathrm{HPO}_{4}, 0.003 \%(\mathrm{w} / \mathrm{v})$ bromocresolpurple, $1 \% \mathrm{D}-\mathrm{glucose}$ and $0.3 \%$ agar in distilled water. Nitrate reduction was detected in Dye's (1962) medium from which $\mathrm{NaCl}$ was omitted. Acid formation from carbohydrates $(1 \%, \mathrm{w} / \mathrm{v})$ was followed in YS-medium $(\mathrm{NaCl}$ omitted), with $0.001 \%$ bromocresol purple as indicator. Growth on carbohydrates $(0.2 \%, w / v)$, alcohols $(0.2 \%, w / v)$, polyphenolic compounds $(0.1 \%, w / v)$, glycosides $(0.1 \%, w / v)$, organic acids $(0.1 \%, w / v)$, DNA bases $(0.1 \%, w / v)$ and $L$-alanine $(0.1 \%, w / v)$ was tested in Starr's (1945) modified medium. The basal medium consisted of $0.005 \%$ yeast extract, $0.1 \% \mathrm{NH}_{4} \mathrm{Cl}, 0.2 \%$ $\mathrm{KH}_{2} \mathrm{PO}_{4}, 0.02 \% \mathrm{MgSO}_{4}, 7 \mathrm{H}_{2} \mathrm{O}, 2 \%$ agar, and was adjusted to $\mathrm{pH} 7.0$. A solution of trace elements, adjusted to pH 7.0 and filter-sterilized, was added separately in order to obtain the following quantities per $100 \mathrm{ml}$ of medium: $2.5 \mu \mathrm{g} \mathrm{H} \mathrm{BO}_{3}, 50 \mu_{\mathrm{g}} \mathrm{CaCO}_{3}, 5 \mu_{\mathrm{g}} \mathrm{CuSO}_{4} .5 \mathrm{H}_{2} \mathrm{O}, 50 \mu_{\mathrm{g}} \mathrm{FeSO}_{4}\left(\mathrm{NH}_{4}\right)_{2} \mathrm{SO}_{4} .6 \mathrm{H}_{2} \mathrm{O}, 0.5 \mu \mathrm{g} \mathrm{KI}, 5 \mu_{\mathrm{g}} \mathrm{MnSO}_{4} . \mathrm{H}_{2} \mathrm{O}$. $5 \mu \mathrm{g} \mathrm{MoO}$ and $25 \mu \mathrm{g} \mathrm{ZnSO} \mathrm{Z}_{4} .7 \mathrm{H}_{2} \mathrm{O}$. The carbon sources to be tested were filter-sterilized; stock solutions of all carbon sources, with the exception of carbohydrates, were adjusted to $\mathrm{pH} 7.0$ before sterilization. Temperature tolerance was observed in a medium containing $0.5 \%$ D-glucose, $0.5 \%$ yeast extract and $0.5 \%$ neutralized peptone in distilled water. Growth in anaerobic conditions was tested on GYEA medium using an anaerobic jar with the Gaspak system (Oxoid). We followed Dye's (1962) procedure for testing growth on L-asparagine as sole source of carbon and nitrogen. Growth tests in the presence of antibiotics, salts and dyes were done on GYEA medium and evaluated after $7 \mathrm{~d}$ incubation. Growth on $0.2 \%(w / v)$ vitamin-free Casamino acids (supplemented with $2.5 \%$ agar) was evaluated after $7 \mathrm{~d}$ incubation.

The suspensions used for the inoculation of liquid media were prepared in distilled water from cells grown for $48 \mathrm{~h}$ on GYCA medium and contained about $10^{8}$ cells per $\mathrm{ml}$. Two droplets were added to the liquid media, which were incubated on a shaking apparatus for $7 \mathrm{~d}$, unless stated otherwise. Solid media in Petri dishes were inoculated with a multipoint inoculator and incubated for $7 \mathrm{~d}$. The incubation temperature was always $28^{\circ} \mathrm{C}$, except for getatinase $\left(20^{\circ} \mathrm{C}\right)$ and temperature-tolerance tests $\left(4,10,32\right.$ and $\left.35^{\circ} \mathrm{C}\right)$.

Phytopathological tests. The pathogenicity of all Xanthomonas campestris pv. oryzae and pv. oryzicola strains was tested on the susceptible rice cultivar TNI. Seedlings were grown in wooden seedboxes and transplanted $10 \mathrm{~d}$ after sowing into clay pots at three seedlings per pot. The inoculum was prepared by suspending a 3-d-old bacterial culture, grown on Wakimoto's medium (see above), in $10 \mathrm{ml}$ sterile distilled water at approximately $10^{9} \mathrm{cells} \mathrm{ml}^{-1}$. Inoculations were performed $40 \mathrm{~d}$ after sowing. Two inoculation methods were applied: (1) the three youngest unfolded leaves from each tiller were inoculated by cutting 1 to $2 \mathrm{~cm}$ from the tip with a pair of scissors, dipped in the inoculum (leaf-clipping method of Kaufiman et al., 1973): (2) the three youngest leaves of another plant were inoculated by rubbing the surface of the blades from the bottom to the tip with a gauze dipped in the inoculum (leafrubbing method). The results were scored after $14 \mathrm{~d}$ by determining the percentage leaf area infected by bacterial blight and bacterial leaf streak symptoms based on the Standard Evaluation System for Rice (Anonymous, 1980).

Unpeeled potatoes were washed thoroughly with tap water and surface-sterilized using the following procedure : immersion in $70 \%(\mathrm{v} / \mathrm{v})$ alcohol for $1 \mathrm{~min}$, flame burning, immersion in fivefold diluted bleach for $5 \mathrm{~min}$, washing in $0.1 \mathrm{M}-\mathrm{HCl}$ and two washings in sterile distilled water. The surface-sterilized potatoes were cut with a sterile knife into slices, which were put into Petri dishes on sterile filter paper (Whatman no. 1), moistened with sterile water. Carrots were immersed for $1 \mathrm{~min}$ in $70 \%$ alcohol and then flamed. Surface-sterilized carrot and potato slices were infected with one droplet of the bacterial suspension and inspected for soft-rot after $2 \mathrm{~d}$ incubation at $28{ }^{\circ} \mathrm{C}$. Sterile water and a soft-rot-causing Erwinia carotovora strain were included as controls. All tests were done in duplicate.

Numerical analysis of phenotypic features. All 133 phenotypic features were coded as 2 (positive) or 1 (negative). Missing features (an average of 0.6 tests per strain) were encoded as $\mathbf{0}$ (no comparison). For the reaction in litmus milk, three states were distinguished: strong peptonization, alkalinization and reduction. Similarities between the strains were calculated with the similarity coefficient of Sokal \& Michener (1958) $\left(S_{S M}\right)$ and Jaccard's coefficient $(S)$ using a modified program of Bonham-Carter (1967). The clustering of the strains was performed according to the unweighted average pair-group method (Sneath \& Sokal, 1973) with the Clustan IC program (Wishart, 1978) using the Siemens 7541 (BS2000) computer of the Centraal Digitaal Rekencentrum, RUG, Gent, Belgium.

Numerical analysis of protein gel electrophoregrams. Strains were grown in Roux flasks on GYCA medium at 


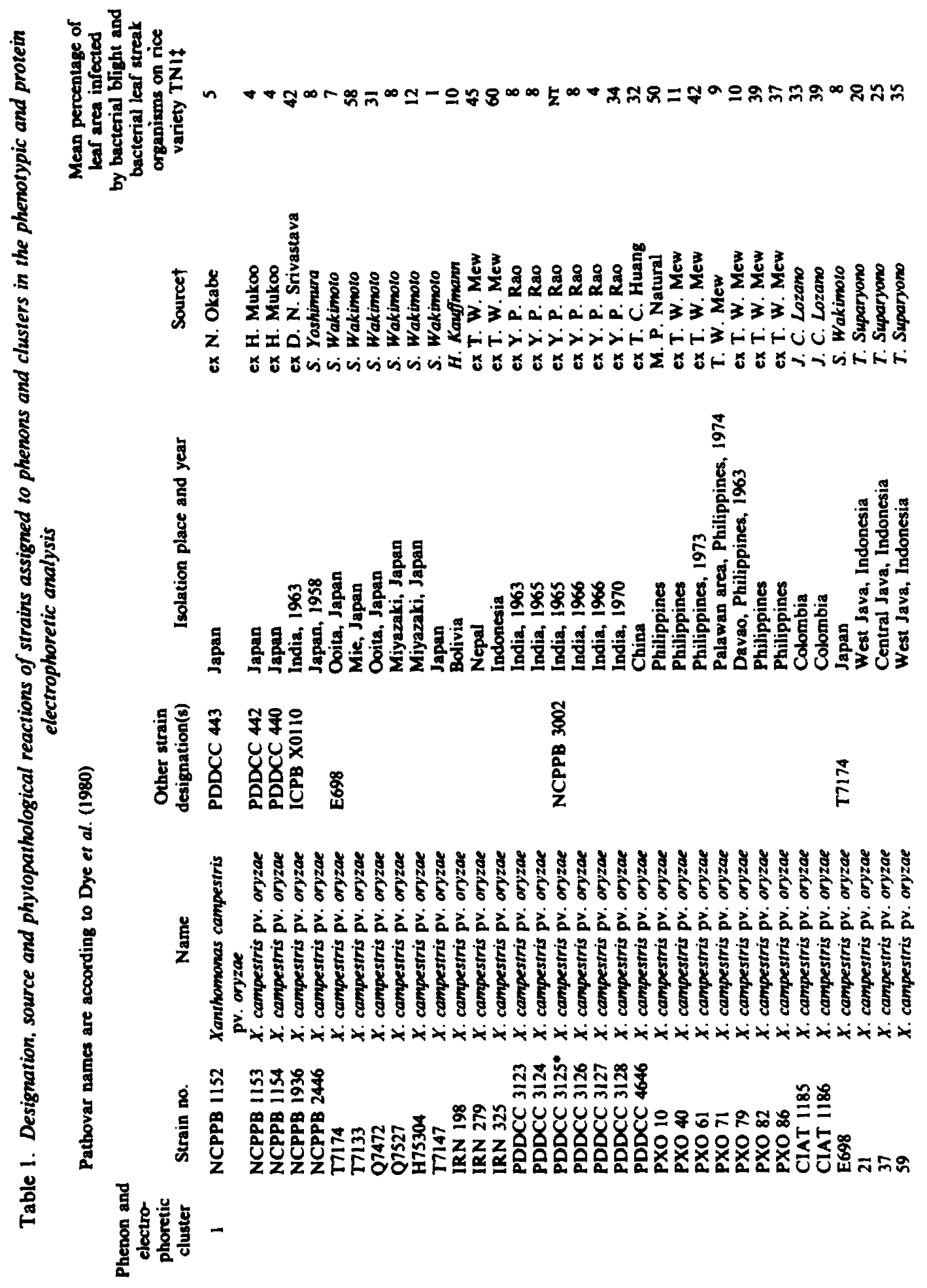




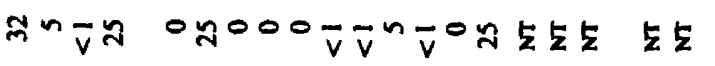

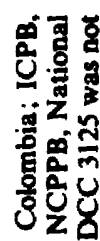

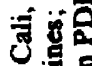

需言易

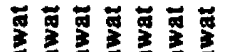

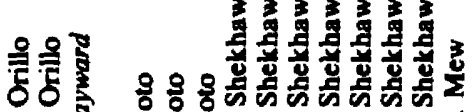

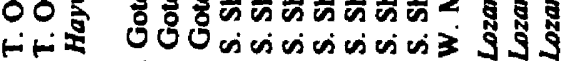

近过

文安

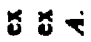
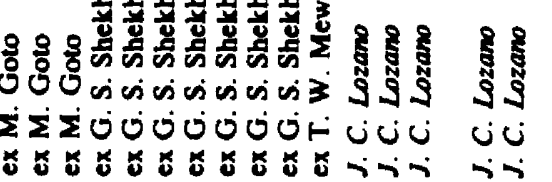

政

密

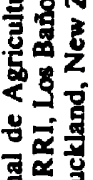

巨ิْ

焉尊

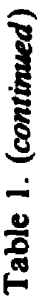

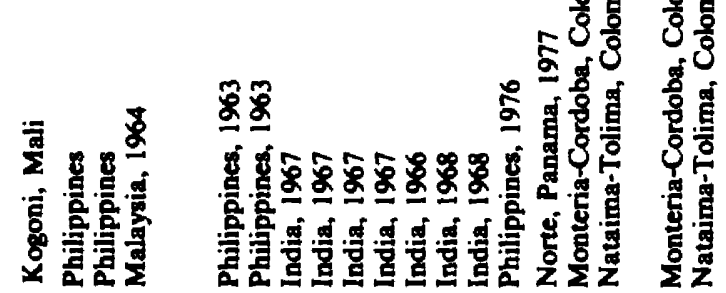

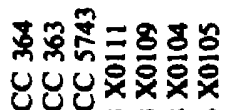

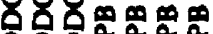

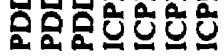

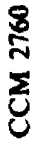

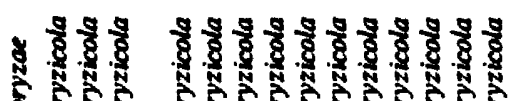

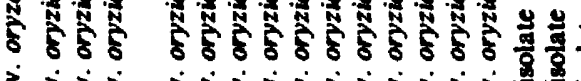

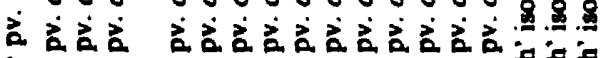

훙

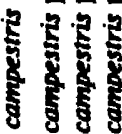

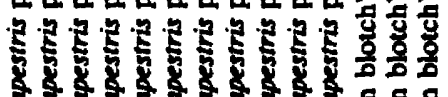

웡

$x x x$

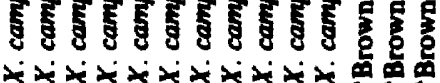

峞畗

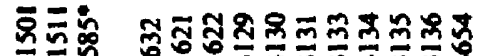

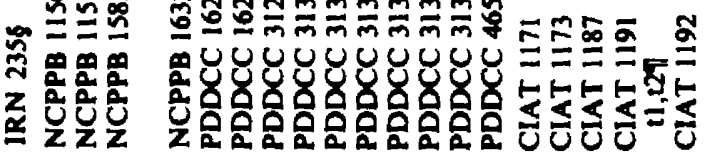

$\underset{*}{\infty}$

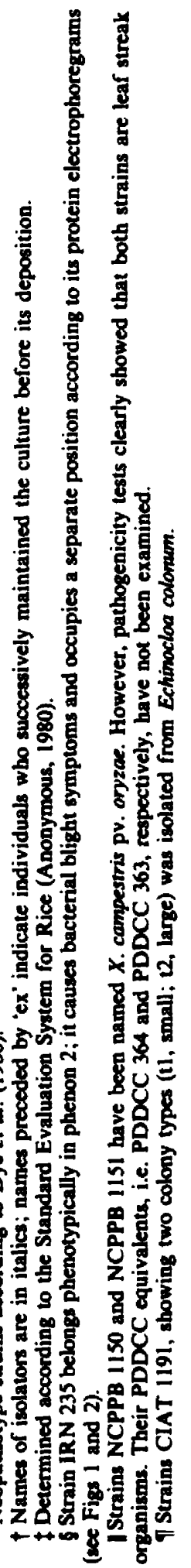



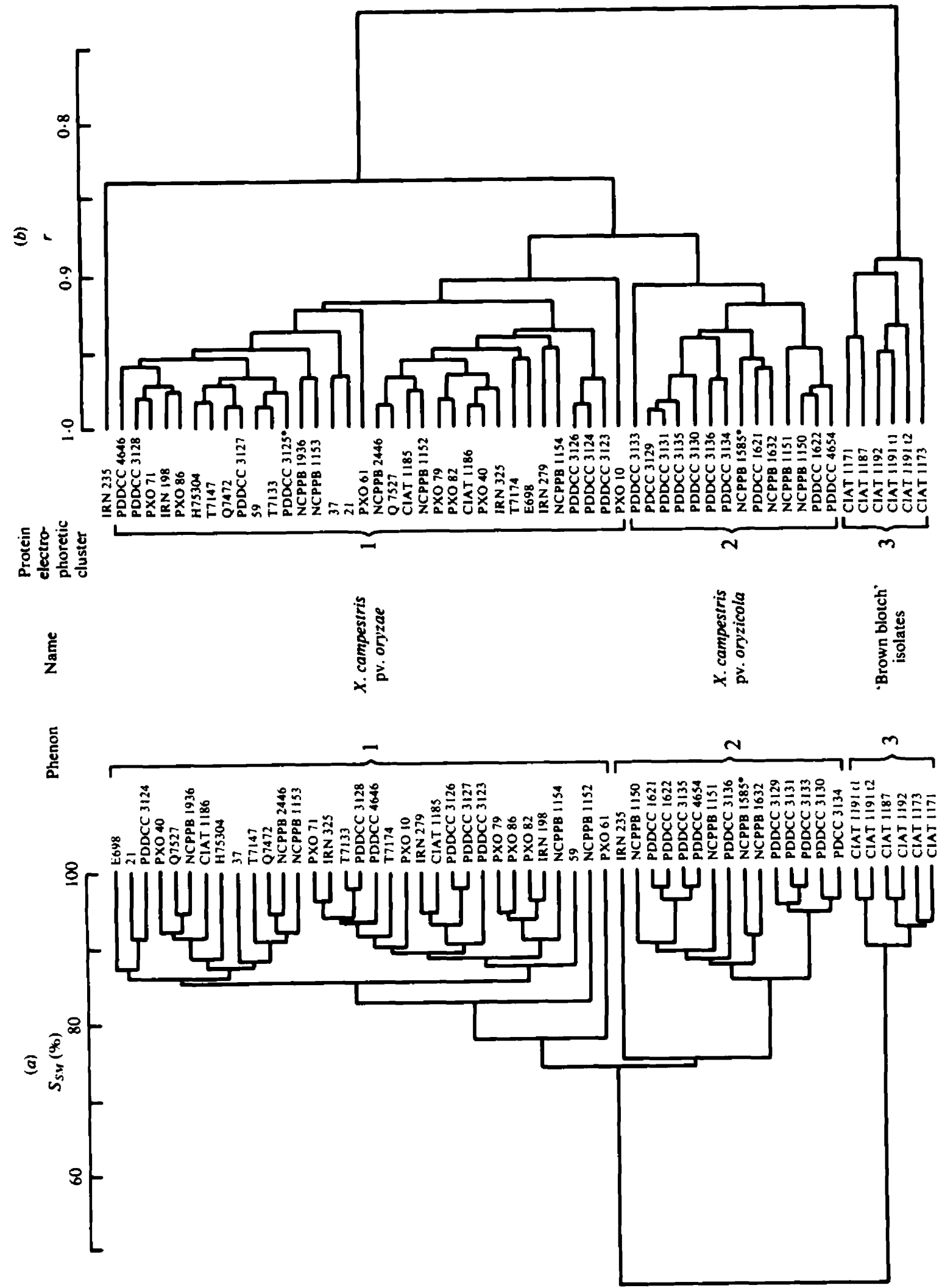
$28^{\circ} \mathrm{C}$ for $40 \mathrm{~h}$ and cells were harvested with $0.01 \mathrm{M}$-phosphate buffer, pH 7-0, vigorously stirred in a mixer (UltraTurrax, Janke \& Kunkel, Staufen, FRG) in order to remove the polysaccharides, centrifuged at $10000_{g}$ for $10 \mathrm{~min}$, and washed twice with $3 \mathrm{~mm}$-Tris/ $\mathrm{HCl}$ buffer, $\mathrm{pH} 7.0$. Cell-free extracts were prepared as described previously (Kersters \& De Ley, 1975), and the soluble protein fraction was dialysed against I litre of 6.4 mm-Tris/HCl buffer, pH 9.2. Polyacrylamide gel electrophoresis, densitometry, photography of the stained gels and normalization of the densitometric tracings were performed by the method of Kersters \& De Ley (1975). Each protein extract was investigated in at least two different electrophoretic experiments. Each normalized densitometric tracing was converted into a sequence of 110 numbers, representing the optical density (expressed as height in $\mathrm{mm}$ ) of each protein on the scan. Computer-assisted calculations of the Pearson product-moment correlation coefficient $(r)$ and clustering by the unweighted average pair-group method were performed as described previously (Kersters \& De Ley, 1975) using the Clustan IC program (Wishart, 1978).

DNA base composition. The average mol $\% \mathrm{G}+\mathrm{C}$ content of the overall genome DNA of $X$. campestris pv. oryzoe NCPPB 1153 and T7147, $X$. campestris pv. oryzicola NCPPB 1585 and the 'brown blotch' isolates CIAT 1171 and CIAT 1173 was measured by the thermal denaturation method (De Ley $\&$ an Muylem, 1963) and calculated by the equation of Marmur \& Doty (1962), as modified by De Ley (1970).

DNA : rRNA hybridizations. The preparation of DNA, fxation of single-stranded high molecular weight DNA on membrane filters, chemical determination of the amount of DNA on the filters, the preparation of [ $\left.{ }^{+4} \mathrm{C}\right] \mathrm{rRNA}$, and the hybridizations between filter-fixed DNA and $16 S$ or $23 S$ [ $\left.{ }^{+} \mathrm{C}\right] \mathrm{R}$ RA were carried out as described by De Vos \& De Ley (1983). Reference [ ${ }^{+} \mathrm{C}$ C]RNAs were prepared from type strains of $X$. campestris pv. campestris (NCPPB 528) and Flawobacterium capsulasum (ATCC 14666). From each DNA : rRNA hybrid two parameters were measured: (1) $T_{\text {m(s) }}$, which is the temperature at which $50 \%$ of the hybrid is denatured; (2) the percentage of rRNA binding, representing the amount of labelled rRNA duplexed, in $\mu \mathrm{g}$ per $100 \mu \mathrm{g}$ DNA fixed on the filter, after ribonuclease treatment.

\section{RESULTS}

\section{Numerical analysis of phenotypic features}

The dendrogram obtained after numerical analysis of 133 unit characters of $34 X$. campestris pv. oryzae, $14 X$. campestris pv. oryzicola and 6 'brown blotch' strains, using the $S_{S M}$ coefficient and the unweighted average pair-group method, is shown in Fig. I (a). At the $73 \% S_{S M}$ level, three phenons can be differentiated. Thirty-three $X$. campestris pv. oryzae strains cluster together at $78 \% S_{S M}$ in phenon 1 . Phenon 2 contains fourteen $X$. campestris pv. oryzicola strains uniting at the $85 \% S_{S M}$ level and one $X$. campestris pv. oryzae strain (IRN 235). The latter strain is only loosely linked to phenon 2 at $74 \% S_{S M}$ (Fig. $1 a$ ). Phenon 3 contains all six 'brown blotch' isolates, clustering together at the $90 \% S_{S M}$ level. The same three phenons were recovered when the $S_{J}$ coefficient was used.

\section{Morphological, physiological and biochemical features}

The following 19 features were uniformly present or gave a positive reaction in all 54 strains examined: cells occurring singly; starch hydrolysis; catalase; oxidative metabolism; acid from D-glucose; growth on D-glucose, D-galactose, cellobiose, sucrose, sodium fumarate, sodium Lmalate, sodium succinate; weak growth at $32^{\circ} \mathrm{C}$ and $10^{\circ} \mathrm{C}$ (not tested for the 'brown blotch' isolates); growth in the presence of $0.001 \%(w / v)$ trimethoprim, $0.005 \%(w / v)$ metronidazole, $0.001 \%(w / v)$ auramin $0,0.0025 \%(w / v)$ thionine, $0.1 \%(w / v)$ actidione. The latter two features have not been tested for the 'brown blotch' isolates.

The following 55 features were uniformly absent or gave a negative reaction in all 54 strains: Gram-reaction; indole production; urease production; 2-ketogluconic acid formation; hydrolysis of egg yolk; nitrate reduction; acid from D-ribose, L-rhamnose, salicin, sorbitol, mesoinositol, dulcitol, adonitol, maltose, lactose, inulin; growth on L-arabinose, D-ribose, Lrhamnose, lactose, raffinose, inulin, methanol, ethanol, $n$-propanol, ethanediol, meso-inositol, sorbitol, dulcitol, adenine, guanine, cytosine, thymine, sodium potassium tartrate, sodium

Fig. 1. Dendrograms showing the relationships between Xanthomonas campestris strains and brown blotch' strains isolated from rice. (a) Phenogram based on the $S_{S M}$ coefficient and the unweighted average linkage algorithm. (b) Clustering of the protein electrophoregrams of the strains based on the correlation coefficient $r$ and the unweighted average linkage algorithm. Neopathotype strains proposed by Dye et al. (1980) are marked*. 
Table 2. Differential phenotypic features between $X$. campestris pv. oryzae (phenon 1), $X$. campestris pv. oryzicola (phenon 2) and 'brown blotch' isolates (phenon 3)

\begin{tabular}{|c|c|c|c|c|}
\hline & & Percents & of strai & cositive \\
\hline & $\begin{array}{l}\text { Phenon number } \\
\text { No. of strains }\end{array}$ & $\begin{array}{lc}\ldots & 1 \\
\ldots & 33\end{array}$ & $\begin{array}{l}2 \\
15\end{array}$ & $\begin{array}{l}3 \\
5\end{array}$ \\
\hline Cells occurring in: & & & & \\
\hline pairs & & $100^{\circ}$ & $100^{*}$ & 0 \\
\hline chains & & 67 & 67 & 0 \\
\hline Occurrence of filaments & & 55 & 60 & 17 \\
\hline Oxidase & & 0 & 0 & 100 \\
\hline Acetoin production & & $\mathbf{0}$ & 93 & 0 \\
\hline Gelatinase activity & & 49 & 100 & $\mathbf{0}$ \\
\hline Reactions in litmus milk: & & & & \\
\hline strong peptonization & & $\mathbf{0}$ & 87 & $\mathbf{0}$ \\
\hline alkalinization & & 97 & 100 & $\mathbf{0}$ \\
\hline reduction & & 94 & 100 & $\mathbf{0}$ \\
\hline Aesculin hydrolysis & & 100 & 100 & 33 \\
\hline Phenylalanine deaminase & & 0 & 53 & 0 \\
\hline Tyrosinase & & 0 & 7 & $\mathbf{0}$ \\
\hline $\mathrm{H}_{2} \mathrm{~S}$ formation from: & & & & \\
\hline peptone & & 100 & 100 & 0 \\
\hline L-cysteine & & 100 & 100 & 67 \\
\hline Hydrolysis of: & & & & \\
\hline Tween 20 & & 88 & 27 & 17 \\
\hline Tween 40 & & 97 & 100 & 100 \\
\hline Tween 60 or Tween 80 & & 100 & 100 & 0 \\
\hline Arbutin hydrolysis & & 91 & 67 & $\mathbf{0}$ \\
\hline Pectinolysis & & 6 & 27 & $\mathbf{0}$ \\
\hline Reduction of potassium tellurite & & 39 & 7 & 100 \\
\hline Acid formation from: & & & & \\
\hline L-arabinose & & 27 & 53 & $\mathbf{0}$ \\
\hline cellobiose & & 100 & 100 & 0 \\
\hline D-fructose & & 91 & 93 & 100 \\
\hline D-galactose & & 97 & 100 & 0 \\
\hline D-mannose & & 85 & 93 & 67 \\
\hline sucrose & & 79 & 100 & 0 \\
\hline trehalose & & 94 & 94 & 0 \\
\hline
\end{tabular}

glyoxylate, 2-ketogluconic acid, tannic acid, p-hydroxybenzoic acid, hydroquinone, phloroglucinol, resorcinol, amygdalin, arbutin, aesculin; growth at $4^{\circ} \mathrm{C}$ or $35^{\circ} \mathrm{C}$; growth in anaerobic conditions; growth in the presence of $0.001 \%(w / v)$ tetracycline hydrochloride, $0.005 \%(w / v)$ chloramphenicol, $0.001 \%(\mathrm{w} / \mathrm{v})$ novobiocin, $0.001 \%(\mathrm{w} / \mathrm{v})$ doxycycline, $3 \% \mathrm{NaCl}, 0.001 \%(\mathrm{w} / \mathrm{v})$ CGA 78039 (7-chloro-6-fluoro-1,4-dihydro-4-oxo-1-ethyl-3-quinoline carboxylic acid), 0.05\% (w/v) crystal violet; growth on L-asparagine as sole source of carbon and nitrogen.

The results of the tests giving differential reactions are given in Table 2. Some tests such as acid formation from and growth on carbon sources, hydrolysis of Tweens, acetoin formation and growth in the presence of inhibitors were repeated for all strains. The average reproducibility was $96 \%$.

\section{Phytopathological properties}

The phytopathogenicity of the strains towards rice variety TNI is indicated in Table 1 . No strain showed any reaction on carrot or potato slices.

\section{Numerical comparison of protein gel electrophoregrams}

More than 150 normalized protein patterns of the 55 strains investigated (Table 1) were compared by numerical analysis. The reproducibility limits were above $r=0.95$ for 48 strains and above $r=0.93$ for the remaining 7 strains. The most typical electrophoregram of each strain (Swings et al., 1976) was used for the final clustering shown in Fig. $1(b)$. At $r=0.89$, three 
Table 2.(continued)

\begin{tabular}{|c|c|c|c|c|}
\hline & & Percen & of str: & posit \\
\hline & $\begin{array}{r}\text { Phenon number } \\
\text { No of strains }\end{array}$ & $\begin{array}{lr}\ldots & 1 \\
\ldots & 33\end{array}$ & $\begin{array}{c}2 \\
15\end{array}$ & $\begin{array}{l}3 \\
5\end{array}$ \\
\hline Growth on sole carbon source: & & & & \\
\hline L-alanine & & 0 & 93 & 100 \\
\hline D-fructose & & 94 & 94 & 100 \\
\hline glycerol & & 0 & 0 & 100 \\
\hline sodium aconitate & & 12 & 60 & 0 \\
\hline sodium L-iactate & & 100 & 100 & 0 \\
\hline sodium oxaloacetate & & 100 & 100 & 83 \\
\hline sodium propionate & & 0 & 0 & 100 \\
\hline trehalose & & 94 & 100 & 100 \\
\hline trisodium citrate & & 73 & 100 & 0 \\
\hline D-xylose & & 100 & 100 & 0 \\
\hline Growth in the presence of $(\%, w / v)$ : & & & & \\
\hline amoxicillin $(0.001)$ & & 3 & 60 & 0 \\
\hline ampicillin $(0.001)$ & & 3 & 93 & 17 \\
\hline cadmium acetate $(0.0001)$ & & 9 & 67 & 33 \\
\hline cupric nitrate $(0.001)$ & & 97 & 7 & 100 \\
\hline erythromycin $(0.001)$ & & 0 & 7 & 100 \\
\hline 8-hydroxyquinoline $(0.001)$ & & 0 & 0 & 100 \\
\hline methicillin $(0 \cdot 005)$ & & 0 & 0 & 100 \\
\hline p-methylaminophenol sulphate $(0.005)$ & & 70 & 100 & 100 \\
\hline neornycin $(0.005)$ & & 15 & 93 & 67 \\
\hline potassium tellurite $(0.001)$ & & 49 & 13 & 100 \\
\hline rifampicin $(0.001)$ & & 0 & 7 & 67 \\
\hline sodium chloride $(0-5-2)$ & & 97 & 100 & 100 \\
\hline sodium formaldehyde sulphoxylate $(0.005)$ & & 46 & 33 & 100 \\
\hline streptomycin $(0.001)$ & & 30 & 100 & 100 \\
\hline $2,4,6,-$ trichlorophenol $(0.005)$ & & 15 & 100 & 100 \\
\hline zinc oxide $(0.001)$ & & 0 & 0 & 100 \\
\hline Growth on $0.2 \%$ vitamin-free Casamino acids after $7 \mathrm{~d}$ & & 0 & 100 & 100 \\
\hline
\end{tabular}

- Although the majority of the cells occurred singly, cells in pairs were also observed in each strain.

electrophoretic clusters could be delineated, corresponding to $X$. campestris pv. oryzae, pv. oryzicola and the 'brown blotch' isolates. One strain of $X$. campestris pv. oryzae (IRN 235) occupied a separate position in the dendrogram. According to the $r$-matrix (not shown) its closest gel electrophoretic neighbours were $X$. campestris pv. oryzae strains T7133, Q7472, H75304 and PDDCC 3128.

The electrophoregrams of strains belonging to each cluster were always very similar upon visual inspection (Fig. 2). The neopathotype strain PDDCC 3125 (=NCPPB 3002) of $X$. campestris pv. oryzae was not included in the phenotypic analysis, but appeared to be a normal member of $X$. campestris pv. oryzae according to its electrophoretic protein pattern (Fig. $1 b, \mathrm{Fig}$. 2).

\section{DNA base composition and DNA :rRNA hybridizations}

The $\mathrm{mol} \% \mathrm{G}+\mathrm{C}$ values of the DNAs of two strains of $X$. campestris pv. oryzae, one strain of $X$. campestris pv. oryzicola and two 'brown blotch' isolates are given in Table 3 . The results of the hybridizations of DNA of these strains versus [ $\left.{ }^{4} \mathrm{C}\right] \mathrm{rRNA}$ of the type strains of $X$. campestris pv. campestris (NCPPB 528) and Flavobacterium capsulatum (A TCC 14666) are compiled in Table 3, together with the $T_{m(e)}$ values and percentages of rRNA binding of the homologous duplexes of these type strains. Hybrids of reference ${ }^{14} \mathrm{C}$-labelled $23 \mathrm{~S}$ rRNA from $X$. campestris pv. campestris NCPPB 528 with DNAs of two strains of $X$. campestris pv. oryzae and one strain of pv. oryzicola had a thermal denaturation midpoint temperature $\left(T_{m(e)}\right)$ range of 80.2 to $80.4{ }^{\circ} \mathrm{C}$ (Table 3). These $T_{m(e)}$ values prove that the generic assignment of $X$. campestris pv. oryzae and 


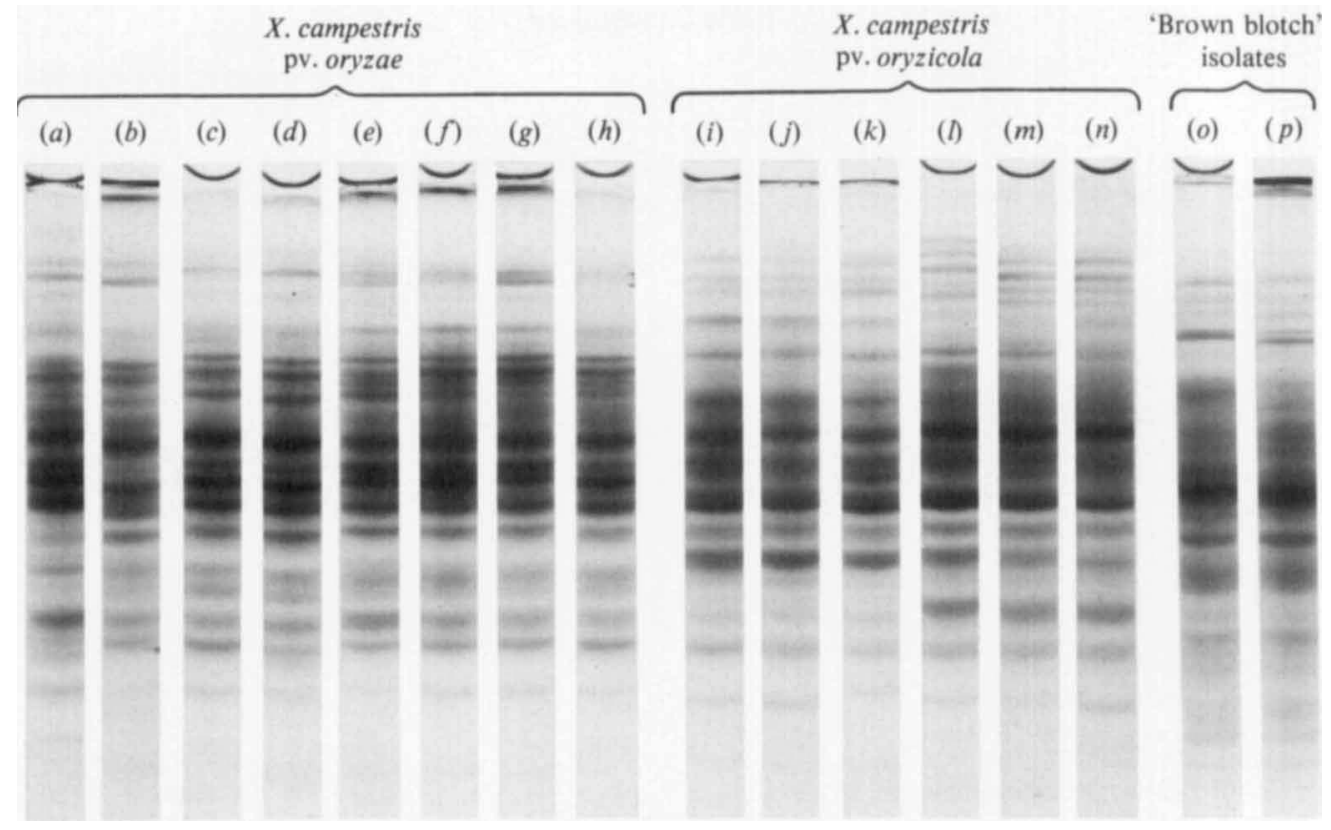

Fig. 2. Normalized protein electrophoregrams from 14 Xanthomonas campestris strains and 2 'brown blotch' strains isolated from rice. Lanes $(a)-(h): X$. campestris pv. oryzae IRN 235, PDDCC 3125 [neopathotype strain proposed by Dye et al. (1980)], PXO 61, PXO 71, PXO 79, PXO 86, NCPPB 1153 , IRN 325. Lanes $(i)$ - $(n): X$. campestris pv, oryzicola NCPPB 1150 , NCPPB 1585 [neopathotype strain proposed by Dye et al. (1980)], PDDCC 1622, PDDCC 3130, PDDCC 3131, PDDCC 3135. Lanes (o) and $(p)$ : 'brown blotch' isolates CIAT 1187 and CIAT 1192.

Table 3. DNA base composition of some $X$. campestris pv. oryzae, pv. oryzicola and 'brown blotch' isolates; results of hybridizations between DNA of these strains and ${ }^{14} \mathrm{C}$-labelled $23 S$ rRNA from the type strains of $X$. campestris pv. campestris and I6S rRNA of Flavobacterium capsulatum

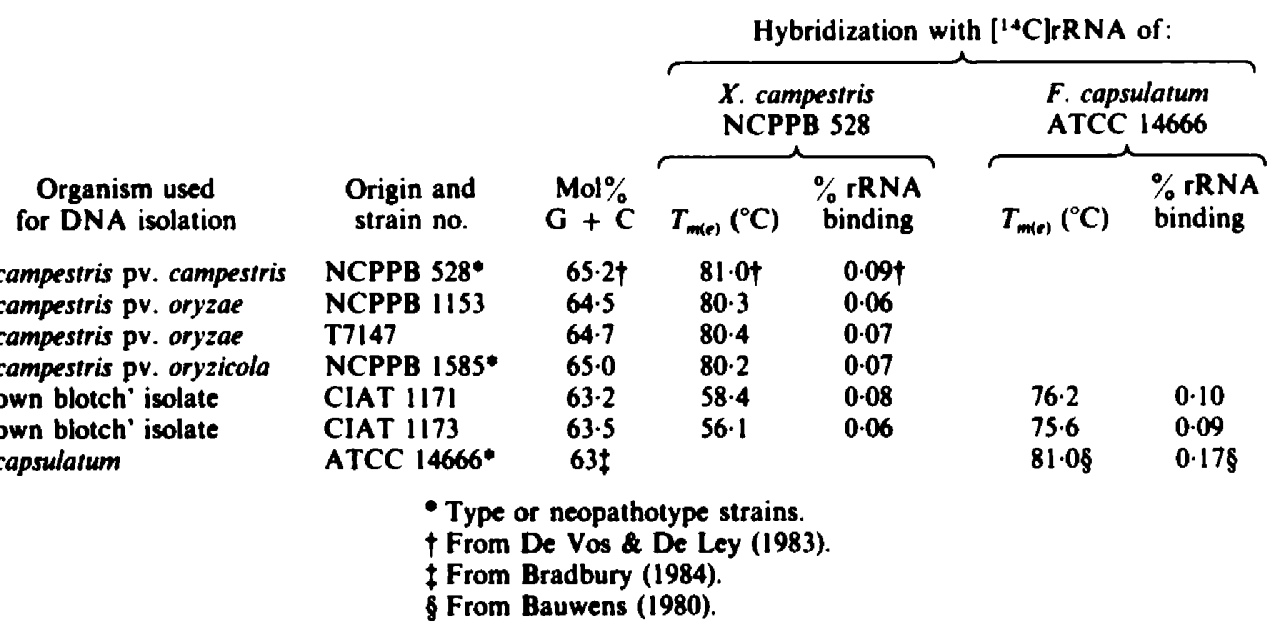

pv. oryzicola is correct. However, in the same conditions, both 'brown blotch' isolates had $\mathbf{T}_{m(e)}$ values of only $56.1{ }^{\circ} \mathrm{C}$ and $58.4^{\circ} \mathrm{C}$, indicating that these strains do not belong to the genus $X a n t h$ omonas, which is a member of the second rRNA superfamily (sensu De Ley, 1978). The relatively high $\mathrm{T}_{\text {m(e) }}$ values of $75.6^{\circ} \mathrm{C}$ and $76.2^{\circ} \mathrm{C}$ of the hybrids of DNA from the 'brown blotch' isolates 
with reference ${ }^{14} \mathrm{C}$-labelled $16 \mathrm{~S}$ rRNA from the type strain of Flavobacterium capsulatum (ATCC 14666) show that these strains belong to the rRNA branch of $F$. capsulatum, which is a member of rRNA superfamily IV (see below).

\section{DISCUSSION}

\section{Morphological, physiological and biochemical features}

All $X$. campestris pv. oryzae and pv. oryzicola strains grew luxuriantly on GYCA medium showing typical yellow-pigmented colonies. On this medium 'brown blotch' isolates produced a somewhat darker yellow non-diffusible pigment.

According to Dye (1962), acetoin is not produced by Xanthomonas. However, in the case of $X$. campestris pv. oryzicola, which was not studied by Dye (1962), a moderate reaction was obvious. In order to test the gelatinase activity we used the classical stab-inoculation method, since Oxoid charcoal discs inhibited the growth of most $X$. campestris pv. oryzae strains. All phenon 2 strains showed a strong gelatinase activity, whereas in phenon 1, some strains were weakly positive or even negative. 'Brown blotch' isolates showed no gelatinase activity. There is no correlation between the gelatinase activity of $X$. campestris pv. oryzae isolates and their pathogenicity towards rice variety TN1, confirming the conclusions of Shekhawat \& Srivastava (1968), Hifni et al. (1975) and Tsuchiya et al. (1982a), but contradicting these from Mukoo \& Isaka (1964).

$X$. campestris pv. oryzicola effects a strong peptonization of litmus milk, together with an alkalinization starting at the top of the medium and a reduction starting from the bottom. In the case of $X$. campestris pv. oryzae, the peptonization was weak, but a clear alkalinization and reduction were observed. 'Brown blotch' isolates showed only a weak peptonization. An alkaline reaction in litmus milk caused by the blight pathogen was also reported by Goto (1964), Mukoo \& Isaka (1964), Reddy \& Ou (1976) and Tsuchiya et al. (1982a).

All strains hydrolysed starch weakly after $7 \mathrm{~d}$. This is in contradiction with the results of Hifni et al. (1975) and Reddy \& Ou (1976), who observed no amylase activity. All $X$. campestris pv. oryzae and pv. oryzicola strains hydrolysed aesculin, whereas only two 'brown blotch' strains (CIAT 191 tl and 12 ) gave a positive reaction. Lozano et al. (1981) did not detect aesculin hydrolysis by 'brown blotch' isolates. In contrast to the results of Hifni et al. (1975), we were unable to demonstrate 2-ketogluconate formation from sodium D-gluconate by resting cells even after $7 \mathrm{~d}$. Hifni et al. (1975) used Benedict's reagent to detect reducing substances, whereas we used $\sigma$ phenylenediamine- $\mathrm{HCl}$ reagent, which yielded a typical blue fluorescent spot with 2-ketogluconic acid under UV light. This reagent is sensitive up to $10 \mu \mathrm{g}$ 2-ketogluconate (Gosselé et al., 1980).

According to Reddy \& Ou (1974), phenylalanine deaminase, tyrosinase and $\beta$-glucosidase activities were absent in $X$. campestris pv. oryzae and occurred in $X$. campestris pv. oryzicola. In our hands, however, the differentiating value of these tests is not so obvious. Phenylalanine deaminase activity was present in $53 \%$ of the $X$. campestris pv. oryzicola strains, but lacking in all strains from phenon 1 and phenon 3 . Tyrosinase activity was only obvious in one strain, i.e. $X$. campestris pv. oryzicola NCPPB 1632. Discrepancies with the results of Reddy \& Ou (1974) were also found for $\beta$-glucosidase activity with arbutin as substrate, as $91 \%$ of the pv. oryzae strains were able to hydrolyse arbutin, whereas only $67 \%$ of the pv. oryzicola strains were able to do so.

All $X$. campestris pv. oryzae and pv. oryzicola strains produced $\mathrm{H}_{2} \mathrm{~S}$ from L-cysteine and less abundantly from peptone. 'Brown blotch' isolates CIAT 1187 and CIAT $1191 \mathrm{t} 2$ did not produce $\mathrm{H}_{2} \mathrm{~S}$ from L-cysteine; none of the 'brown blotch' isolates formed $\mathrm{H}_{2} \mathrm{~S}$ from peptone.

The hydrolyse of Tweens 60 and 80 clearly differentiates phenons 1 and 2 (positive) from phenon 3 (negative). Hydrolysis of sodium polygalacturonate was only observed for a few strains, i.e. $X$. campestris pv. oryzae IRN 235, IRN 279, PDDCC 3124 and $X$. campestris pv. oryzicola NCPPB 1151, PDDCC 3131 and PDDCC 3136. There is no correlation between the pathogenicity towards rice variety TN1 and pectinolytic activity, confirming the findings of Hifni et al. (1975).

From Table 2 it is apparent that the 'brown blotch' isolates acidified a smaller number of carbohydrates than $X$. campestris pv. oryzae and pv. oryzicola. Acid formation from D-fructose was 
evident after $24 \mathrm{~h}$ for the 'brown blotch' isolates, whereas many pv. oryzae and pv. oryzicola strains showed acidification only after $4 \mathrm{~d}$. The absence of acid formation from D-galactose, cellobiose and trehalose clearly differentiates the 'brown blotch' isolates from pv. oryzae and pv. oryzicola. This confirms the data of Lozano et al. (1981). There are no striking contradictions between our results on acid formation by $X$. campestris pv. oryzae and those obtained by Goto (1964), Mukoo \& Isaka (1964), Shekhawat \& Srivastava (1968), Hifni et al. (1975), Reddy \& Ou (1976) and Tsuchiya et al. (1982a).

The majority of the $X$. campestris pv. oryzae and pv. oryzicola strains were able to grow on Dxylose, D-glucose, D-galactose, D-fructose, cellobiose, sucrose, trehalose, sodium L-lactate and the Krebs' cycle intermediates sodium fumarate, sodium L-malate, sodium oxaloacetate and sodium succinate. (Poly)alcohols, polyphenols and their glycosides, and DNA bases are not suitable carbon sources for the growth of isolates from 'brown blotch', $X$. campestris pv. oryzae or $\mathrm{pv}$. oryzicola strains. Inhibition reactions may occur : e.g. benzoic acid, added to GYEA basal medium at $0.01 \%(w / v)$ inhibits growth of both $X$. campestris pv. oryzae and pv. oryzicola. The growth tests on D-xylose, sodium L-lactate, glycerol, sodium propionate and L-alanine are useful features for the differentiation between the three plant pathogens. The $\mathrm{pH}$ is of utmost importance in these growth tests: below pH 5.5, growth on D-xylose, D-galactose, cellobiose, sucrose and trehalose was significantly reduced. None of the strains was able to grow anaerobically. When the inoculated plates were again incubated in normal atmospheric conditions after $7 \mathrm{~d}$ anaerobic incubation, growth did not recommence.

Some antibiotics inhibited the growth of $X$. campestris pv. oryzae and pv. oryzicola strains at low concentrations: tetracycline. $\mathrm{HCl}$, novobiocin or doxycycline at $0.001 \%(\mathrm{w} / \mathrm{v})$, and chloramphenicol at $0.005 \%(w / v)$. The 'brown blotch' isolates were the only strains which were able to grow in the presence of $0.005 \%(w / v)$ methicillin. Xanthomonas campestris pv. oryzicola is on the whole more resistant to antibiotics than pv. oryzae. This is especially obvious in the case of $0.001 \%(\mathrm{w} / \mathrm{v})$ ampicillin. Unlike the majority of the $X$. campestris pv. oryzae strains, $X$. campestris pv. oryzae IRN 235 is resistant to $0.005 \%(\mathrm{w} / \mathrm{v})$ neomycin and $0.001 \%(\mathrm{w} / \mathrm{v})$ streptomycin, ampicillin or amoxycillin, thus resembling more the $X$. campestris pv. oryzicola strains. Cupric nitrate added to GYEA basal medium at $0.001 \%(w / v)$, permits a clear-cut differentiation between $X$. campestris pv. oryzae (resistant) and pv. oryzicola (susceptible).

All $X$. campestris pv. oryzicola and 'brown blotch' strains grew on $0.2 \%$ vitamin-free Casamino acids without carbon source.

\section{Taxonomy of $X$. campestris $p v$. oryzae, pv. oryzicola and 'brown blotch' isolates}

An excellent overall correlation was found between the groupings obtained by numerical analysis of phenotypic features and of protein electrophoregrams (Table 1, Fig. 1). All the $X$. campestris pv, oryzae strains, except IRN 235, belonged in phenon 1 and the electrophoretic cluster 1 ; all the $X$. campestris pv. oryzicola strains grouped in phenon 2 and electrophoretic cluster 2; the 'brown blotch' isolates constituted a separate phenon 3 and electrophoretic cluster 3 (Fig. 1). The excellent agreement between the groupings obtained by totally different approaches means that the numerical data can be interpreted with confidence.

The $X$. campestris pv. oryzae and pv. oryzicola strains investigated fit well in the phenotype definition of the genus Xanthomonas given by Bradbury (1984). The features of the strains from both pathovars correspond to those of $X$. campestris as given by Dye \& Lelliott (1974) and Bradbury (1984). Only one aberration, i.e. the absence of growth at $35^{\circ} \mathrm{C}$, was found for both pathovars. Furthermore, the mol $\% \mathrm{G}+\mathrm{C}$ values of the DNAs of two $X$. campestris pv. oryzae strains $(64.5$ and $64.7 \mathrm{~mol} \% \mathrm{G}+\mathrm{C})$ and one $X$. campestris pv. oryzicola strain $(65.0 \mathrm{~mol} \% \mathrm{G}+\mathrm{C})$ fit well in the mol \% G + C range of 63.5 to 69.2 reported for the Xanthomonas campestris group (Bradbury, 1984). Murata \& Starr (1973) determined mol \% $G+C$ values for $X$. campestris pv. oryzae of 64.4 and for $X$. campestris pv. oryzicola of 68.9. DNA : rRNA hybridizations (Table 3, Fig. 3) confirmed that $X$. campestris pv. oryzae and $X$. campestris pv. oryzicola belong to Xanthomonas. De Vos \& De Ley (1983) found that this genus constitutes a separate rRNA branch of the second rRNA superfamily, together with the rRNA branches of Pseudomonas fluorescens, 


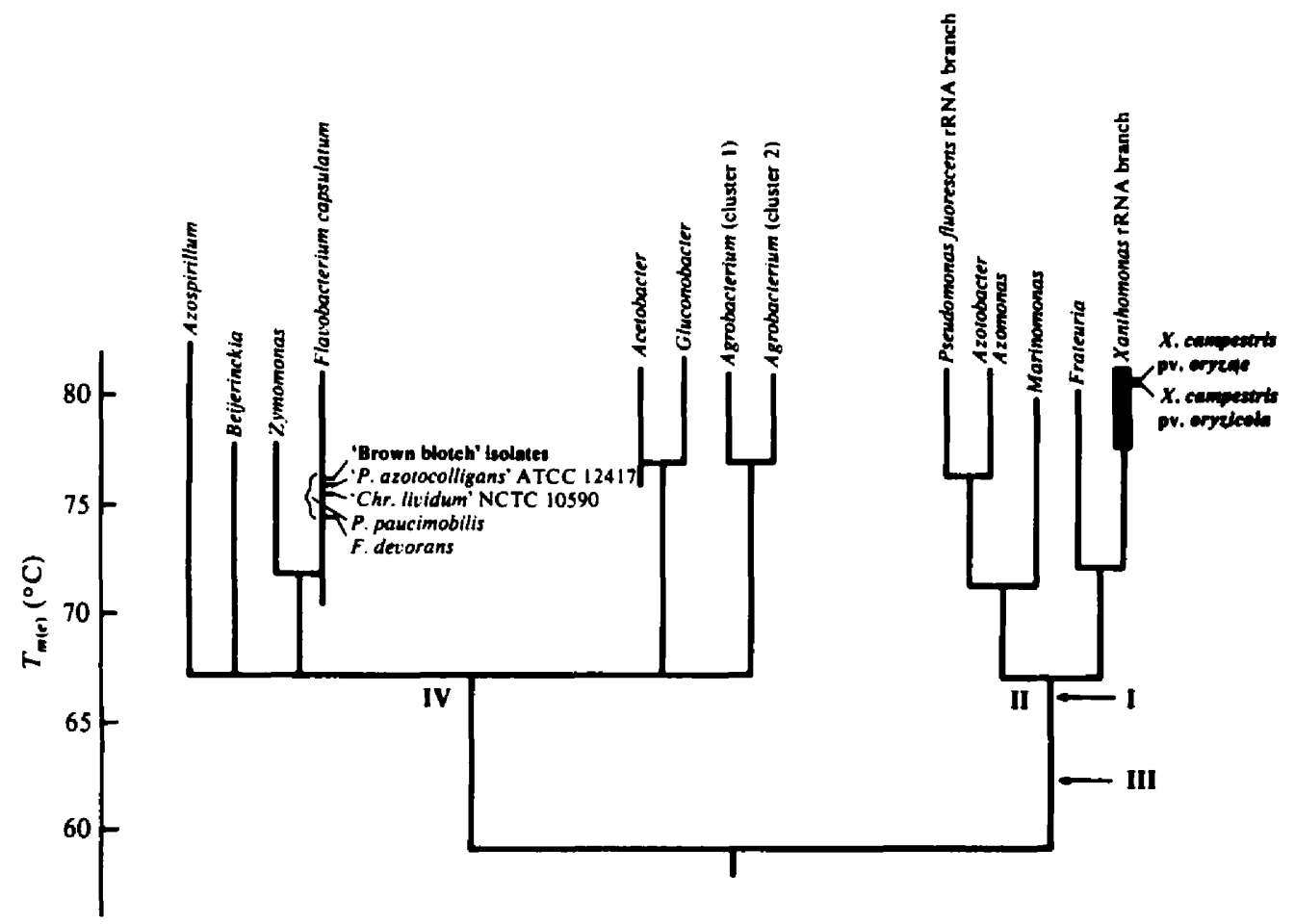

Fig. 3. Position of Xanthomonas campestris pv. oryzae, X. campestris pv. oryzicola and the 'brown blotch' isolates in the second and fourth rRNA superfamilies. The rRNA cistron similarities are expressed as $T_{\text {met }}$ values of DNA : rRNA hybrids. Not all known finer divisions of the branches are represented. The solid bar indicates the extent (heterogeneity) of the genus Xanthomonas. The roman numerals indicate the roots of the rRNA superfamilies. Data were obtained from the following sources: De Smedt \& De Ley (1977), De Ley et al. (1978), De Smedt et al. (1980), Gillis \& De Ley (1980), Swings et al. (1980), Bauwens (1980), Bauwens \& De Ley (1981), De Vos \& De Ley (1983), Swings et al. (1983), Van Landschoot \& De Ley (1983).

Azomonas, Azotobacter, Frateuria (De Smedt et al., 1980; Swings et al., 1980), and Marinomonas (Van Landschoot \& De Ley, 1983) (Fig. 3).

Numerical analysis of phenotypic features and protein electrophoregrams indicated that the 'brown blotch' strains were considerably different from $X$. campestris pv. oryzae and pv. oryzicola (Figs 1 and 2). DNA :rRNA hybridizations unequivocally proved that the 'brown blotch' isolates are not members of the genus Xanthomonas (Table 3). The 'brown blotch' isolates belong on the rRNA branch of the misnamed Flavobacterium capsulatum. The following species or strains have $T_{m(e)}$ values in the vicinity of the 'brown blotch' isolates: Pseudomonas paucimobilis, Flavobacterium devorans, 'Pseudomonas azotocolligans' ATCC 12417 [not on the Approved Lists of Bacterial Names (Skerman et al., 1980)], and 'Chromobacterium lividum' strains NCTC 10590 and NCTC 10591 (Bauwens \& De Ley, 1981). All these organisms have been generically misnamed. Further investigations are required to determine the degree of relatedness of the "brown blotch' isolates to the above mentioned taxa. These are all members of the fourth rRNA superfamily (sensu De Ley, 1978), which is constituted by a number of genera such as Acetobacter, Gluconobacter, Agrobacterium, Rhizobium, Zymomonas, Beijerinckia, Azospirillum, Spirillum, Rhodopseudomonas, etc. (De Smedt \& De Ley, 1977; Gillis \& De Ley, 1980; De Smedt et al., 1980; M. Gillis \& J. De Ley, unpublished). It should be recalled here that $F$. capsulatum and $F$. devorans (both $65 \mathrm{~mol} \% \mathrm{G}+\mathrm{C}$ ) (Holmes et al., 1984) are very different from the type species Flavobacterium aquatile $(32 \mathrm{~mol} \% \mathrm{G}+\mathrm{C})$ and that the named flavobacteria are distributed over at least six taxonomically widely different rRNA branches (Bauwens, 1980; Bauwens \& De Ley, 
Table 4. Differentiation between $X$. campestris pv. oryzae, $X$. campestris pv. oryzicola and 'brown blotch' isolates

,$+ \geq 90 \%$ of the strains gave positive reactions;,$-<10 \%$ of the strains gave positive reactions.

\begin{tabular}{|c|c|c|c|}
\hline & $\begin{array}{l}X \text {. campestris } \\
\text { pv. oryzae }\end{array}$ & $\begin{array}{l}X \text {. campestris } \\
\text { pv. oryzicola }\end{array}$ & $\begin{array}{l}\text { 'Brown blotch' } \\
\text { isolates }\end{array}$ \\
\hline Oxidase & - & - & + \\
\hline Acetoin production & _ & + & - \\
\hline $\mathrm{H}_{2} \mathrm{~S}$ from peptone & + & + & - \\
\hline $\begin{array}{l}\text { Hydrolysis of Tween } 60 \\
\text { and Tween } 80\end{array}$ & + & + & - \\
\hline $\begin{array}{l}\text { Acid from D-galactose. } \\
\text { cellobiose and trehalose } \\
\text { Growth on sole carbon source: }\end{array}$ & + & + & - \\
\hline D-xylose or sodium L-lactate & + & + & _* \\
\hline Blycerol or sodium propionate & - & - & + \\
\hline L-alanine & - & + & + \\
\hline Resistance towards $(\%, w / v)$ : & & & \\
\hline methicillin (0.005) & - & - & + \\
\hline cupric nitrate $(0.001)$ & + & - & + \\
\hline 8-hydroxyquinoline $(0.001)$ & - & - & + \\
\hline zinc oxide $(0.001)$ & - & - & + \\
\hline Growth on $0.2 \%$ vitamin-free & - & + & + \\
\hline
\end{tabular}

1981). The phenotypic features of the 'brown blotch' isolates correspond roughly to the description of $P$. paucimobilis by Holmes et al. (1977).

The phenotypic differentiation between $X$. campestris pv. oryzae, $X$. campestris pv. oryzicola and the 'brown blotch' isolates is given in Table 4.

\section{The fine taxonomic structure of $X$. campestris pv. oryzae}

No phenotypic features were found allowing a subdivision of $X$. campestris pv. oryzae. This taxon is also fairly homogeneous on the basis of the protein electrophoregrams (Figs 1 and 2). In the phenotypic analysis two strains (PXO 61 and NCPPB 1152) clustered at a lower level in phenon I, and strain IRN 235 grouped at the border of phenon 2. The latter strain occupied a separate position according to its protein electrophoretic pattern (Figs 1 and 2). However, this strain causes bacterial blight symptoms, typical of $X$. campestris pv. oryzae (Table 1). Hifni et al. (1975), Reddy \& Ou (1976) and Tsuchiya et al. (1983a) were likewise not able to define biochemical groups within $X$. campestris pv. oryzae. The geographical distribution of the strains was not reflected in the dendrogram. Highly virulent and weakly virulent strains were intertwined in both dendrograms. The protein electrophoregram of the highly virulent strain IRN 325 (isolated in Indonesia) was almost indistinguishable from the pattern of the less virulent strain NCPPB 1153 (isolated in Japan) (Table I; Fig. 2).

Classification systems for $X$. campestris pv. oryzae strains, based on their virulence on rice varieties bearing different major genes for resistance towards bacterial blight, have been developed in Japan (Ezuka \& Sakaguchi, 1978) and in the Philippines (Mew \& Vera Cruz, 1979), and five and four pathogenic groups, respectively, have been proposed within $X$. campestris pv. oryzae. In our phenotypic and gel electrophoretic analyses, we included representative strains of both systems of pathogenic groups: the Philippine groups I, II, III and IV were represented respectively by strains PXO 61, PXO 86, PXO 79 and PXO 71, whereas strains T7174, T7147, T7133 and H75304 were chosen from the Japanese pathogenic groups I, II, III and V, respectively. No representative of group IV was available. It can be concluded from Fig. 1 that there is no correlation between the clustering obtained from phenotypic analyses with $S_{S M}$ or $S_{J}$ coefficients and the pathogenic races of $X$. campestris pv. oryzae. No biochemical or physiological features were found that differentiated the pathogenic groups or correlated with the virulence of the strains. 
This confirms the conclusions of Reddy \& Ou (1976) and Tsuchiya et al. (i982a). Also, the protein electrophoregrams of strains PXO 61, PXO 86, PXO 79 and PXO 71 (Fig. 2) were very similar, suggesting a high degree of relatedness between the Philippine groups I, II, III and IV. Bacteria displaying a strong similarity in their electrophoretic protein patterns are known to share a high degree of DNA relatedness (Kersters \& De Ley, 1980; Izard et al., 1981 ; Owen \& Jackman, 1982). We can therefore conclude that all the investigated strains of $X$. campestris $p v$. oryzae, except strain IRN 235, constitute a genetically homogeneous group of bacteria, and that the subdivision in pathogenic races is determined by only a minute fraction of the genetic material of the cell.

The fine taxonomic structure of $X$. campestris pv. oryzicola

Within the $X$. campestris pv. oryzicola group all strains isolated in India by G. S. Shekhawat in 1966 and 1967 formed a small phenotypic subgroup, whereas strains PDDCC 3135 and PDDCC 3136, isolated in India in 1968, clustered with the other $X$. campestris pv. oryzicola strains isolated in the Philippines and Malaysia (Fig. 1 a). The protein electrophoregrams revealed that all the strains isolated in India (including PDDCC 3135 and PDDCC 3136) shared a common heavy protein band at $44 \mathrm{~mm}$ from the top of the gel (Fig. 2). This common characteristic is reflected in the numerical analysis of the patterns (Fig. 1b). There is no correlation between the virulence of the strains and their position in the dendrogram or with any phenotypic feature. The protein patterns of the highly virulent strain NCPPB 1585 (neopathotype strain, isolated in Malaysia) and the non-virulent strain PDDCC 1622 (isolated in the Philippines) were very similar (Fig. 2). It has to be mentioned that within $X$. campestris pv. oryzicola no pathogenic races could be distinguished (Ou et al., 1971).

J. D. L. and J. S. are indebted to the Ministerie van Buitenlandse Betrekkingen (Belgium) for a grant. We also thank Professor Dr S. Wakimoto, Dr T. W. Mew, Dr J. C. Lozano, Dr T. Suparyono, Dr M. Goto and Dr D. Dye for sending us strains.

J. S. and K. K. are grateful to the Nationaal Fonds voor Wetenschappelijk Onderzoek (Belgium) for research grants and J. D. L. is indebted to the Fonds voor Kollektief en Fundamenteel Onderzoek (Belgium) for research and personnel grants.

\section{REF ERENCES}

Aldrick, S. J., Buddenhugen, I. W. \& Reddy, A. P. K. (1973). The occurrence of bacterial leaf blight in wild and cultivated rice in northern Australia. Australian Journal of Agricultural Research 24. 219-227.

ANONYMOUs (1970). Bacterial leaf blight of rice plant in South-eastem Asia, Overseas Technical Cooperation Agency of Japan, pp. 1-71.

ANONYMOUS (1980). Standard evaluation system for rice, IRRI, 2nd edn. International Rice Test Program. IRRI, Los Baños, Laguna, Philippines.

BARRITT, M. M. (1936). The intensification of Voges Proskauer reaction by the addition of $\alpha$-naphthol. Journal of Pathological Bacteriology 42, 441 454.

BAUWENS, M. (1980). DNA:rRNA hybridisaties in de identificatie en de klassificatie van heterotrofe bakterien: de heterogeniteit van het zogenaamde genus Flavobacterium. PhD thesis. Rijksuniversiteit Gent, Belgium.

BAuWENS, M. \& DE LEY, J. (1981). Improvements in the taxonomy of Flawobacterium by DNA:rRNA hybridizations. In The Flawobacterium-Cytophaga Group, pp. 27-31. Edited by H. Reichenbach \& O. B. Weeks. Weinheim: Verlag Chemie.

BerAHA, L. (1968). A rapid method for the preparation of a semi-solid agar medium for detection of pectolytic enzyme activity in Erwinia carotowora. Plant Disease Reporter 52, 167.

Bonham-CaRter, G. F. (1967). Fortran IV Program for $Q$-mode Cluster Analysis of Nonquantitative Data using IBM 7090/7094 Computers. Kansas Geological Survey Computer Program. The University of Kansas, Lawrence, USA.

BrADbury, J. F. (1984). Genus II. Xanthomonas. In Bergey's Manual of Systematic Bacteriology, pp. 199210. Edited by N. R. Krieg. Baltimore: Williams \& Wilkins.

Buddenhugen, I. W., Vuong, H. H. \& BA, D. D. (1979). Bacterial blight found in Africa. Intermational Rice Research Newsletter 4, 11.

Chol, J. E., Matsuyama, N. \& Wakimoto, S. (1980). Serovars of Xanthomonas campestris pv. oryzae collected from Asian countries. Annals of the Phytopathological Society of Japan 46, 209-215.

DE LEY, J. (1970). Reexamination of the association between melting point, buoyant density, and chemical base composition of deoxyribonucleic acid. Journal of Bacteriology 101, 738-754.

DE LEY, J. (1978). Modern methods in bacterial taxonomy. Evaluation, application, prospects. In Proceedings of the th International Conference on Plant Pathogenic Bacteria, Angers, pp. 347-357. Tours, France: Gibert-Clarey. 
De Ley, J. \& Van MuYlem, J. (1963), Some applications of deoxyribonucleic acid base composition in bacterial taxonomy. Amtonie uan Leewwenhoek 29, 344-358.

De LeY, J., Seobrs, P. \& Gillis, M. (1978). Intra- and intergeneric similarities of Chromobacterium and Janhinobacterium ribosomal ribonucleic acid cistrons. Intermational Joumal of Systematic Bacteriology 28, 154-168.

De SyedT, J. \& De LeY, J. (1977). Intra- and intergeneric similarities of Agrobacterium ribosomal ribonucleic acid cistrons. International Joumal of Systematic Bacteriology 27, 222-240.

De SMedT, J., BAuWens, M., TYtont, R. \& De LeY, J. (1980). Intra- and intergeneric similarities of ribosomal ribonucleic acid cistrons of free-living nitrogenfixing bacteria. Insernational Joumal of Systematic Bacteriology 30, 106-122.

DE Vos, P. \& DE LEY, J. (1983). Intra- and intergeneric similarities of Pseudomonas and Xanthomonas ribosomal ribonucleic acid cistrons. International Journal of Systematic Bacteriology 33, 487-509.

Dictinson, C. H., Austin, B. \& Goodfellow, M. (1975). Quantitative and qualitative studies of phylloplane bacteria from Lolium perenne. Journal of General Microbiology 91, 157-166.

DYe, D. W. (1962). The inadequacy of the usual determinative tests for the identification of Xanthomonas spp. New Zealand Journal of Science 5, 393-416.

Dre, D. W. (1978). Genus IX Xanthomonas Dowson 1939. In: Young, J. M., Dye, D. W., Bradbury, J. F., Panagopoulos, C. G. \& Robbs, C. F. A proposed nomenclature and classification for plant pathogenic bacteria. New Zealand Joumal of Agricultural Research 21, 153-177.

DYB, D. W. LELlotT, R. A. (1974). Xanthomonas. In Bergey's Manual of Determinative Bacteriology, 8th edn., pp. 243-249. Edited by R. E. Buchanan \& N. E. Gibbons. Baltimore: Williams \& Wilkins.

DYe, D. W., Bradsury, J. F., Goto, M., HaYWard, A. C., Lelliott, R. A. \& SChoth, M. N. (1980). International standards for naming pathovars of phytopathogenic bacteria and a list of pathovar names and pathotype strains. Review of Plant Pathology 59, 153-168.

Ewino, W. H., Davis, B. R. \& Reavis, R. W. (1957). Phenylalanine and malonate media and their use in enteric bacteriology. Public Health Laboratory 15, 153.

EzUrA, A. \& SAruoucrn, S. (1978). Host-parasite relationship in bacterial leaf blight of rice caused by Xanthomonas oryzae. Review of Plant Protection Research Japan 11, 93-118.

Fano, C. T., Ren, H. C., Chen, T. Y., Chu, Y. K., FauN, H.C. WU,S. C. (1957). A comparison of the rice bacterial leaf blight organism with the bacterial leaf streak organism of rice and Leersia hexandra Schwartz. Acta phytopathologica sinica 3, 99-124.

GILLL, M. DE LEY, J. (1980). Intra- and intergeneric similarities of the ribosomal ribonucleic acid cistrons of Acetobacter and Gluconobacter. Intemational Journal of Systematic Bacteriology 30, 7-27.

Gosselé, F., Swinas, J. \& DE LeY, J. (1980). A rapid, simple and simultaneous detection of 2-keto-, 5-ketoand 2,5-diketogluconic acids by thin-layer chromatography in culture media of acetic acid bacteria.
Zentralblatt für Bakteriologie und Hygiene I Abt. Orig. C1, 178-181.

Goro, M. (1964). 'Kresek' and pale yellow leaf, systemic symptoms of bacterial leaf blight of rice caused by Xanthomonas oryzae (Uyeda et Ishiyama) Dowson. Plant Disease Reporter 48, 858-861.

Hipn, H. R., Nishiyama, K. \& EzUKA, A. (1975). Bacteriological characteristics of some isolates of Xanthomonas oryzae different in their pathogenicity and locality. Contributions of the Central Research Institute of Agriculture of Bogor 16, 1-18.

Holmes, B., OWen, R. J., Evans, A., Malnick, H. \& WILLCOX, W. R. (1977). Pseudomonas paucimobilis, a new species isolated from human clinical specimens, the hospital environment, and other sources. International Journal of Systematic Bacteriology 27. 133-146.

Holmes, B., Owen, R. J. \& McMeerin, T. A. (1984). Genus Flavobacterium. In Bergey's Manual of Systematic Bacteriology, vol. 1, pp. 353-361. Edited by N. R. Krieg. Baltimore: Williams \& Wilkins.

Ishryama, S. (1922). Studies of bacterial leaf blight of rice. Report of the Imperial Agricultural Station, Konosu 45, 233-261.

Izard, D., Ferragut, C., Gavint, F., Kersters, K., DE LeY, J. \& LeCLeRc, H. (1981). Klebsiella terrigena: a new species from soil and water. Intemational Journal of Systematic Bacteriology 31, 116-127.

KaUffyan, H. E., Reddy, A. P. K., Hsieh, S. P. Y. \& Merca, S. D. (1973). An improved technique for evaluating resistance of rice varieties to $\boldsymbol{X}$. oryzae. Plant Disease Reporter 57, 537-541.

Kersters, K. \& De LEY, J. (1975). Identification and grouping of bacteria by numerical analysis of their electrophoretic protein patterns. Journal of General Microbiology 87, 333-342.

Kersters, K. \& De Ley, J. (1980). Classification and identification of bacteria by electrophoresis of their proteins. In Microbial Classification and Identification. Edited by M. Goodfellow \& R. G. Board. Society for Applied Bacteriology, Symposium Series no. 8. London: Academic Press.

Kovacs, N. (1928). Eine vereinfachte Methode zum Nachweis der Indolbildung durch Bakterien. Zeitschrift fur Immunitatsforschung und experimentelle Therapie 55, 311-315.

Kovacs, N. (1956). Identification of Pseudomonas pyocyanea by the oxidase reaction. Nature, London $178,703$.

Lozano, J. C. (1977). Identification of bacterial leaf blight in rice, caused by Xanthomonas oryzae, in America. Plant Disease Reporter 61, 644-648.

Lozano, J. C., Victoria, J., Velasco, A. C. \& AhN, S. W. (1981). Bacterial brown blotch, a disease of rice in tropical America. Proceedings of the fift $h$ International Conference on Plant Pathogenic Bacteria, Cali, Colombia, pp. 65-73.

Maru(UR, J. DoTy, P. (1962). Determination of the base composition of deoxyribonucleic acid from its thermal denaturation temperature. Journal of Molecular Biology 5, 109-118.

Mew, T. W. \& Vera Cruz, C. M. (1979). Variability of Xanthomonas oryzae specificity in infection of rice differentials. Phytopathology 69, 152-155.

MizuraMI, T. \& Warmoto, S. (1969). Epidemiology 
and control of bacterial leaf blight of rice. Anmual Review of Phylopathology 7, 51-72.

MuKoO, H. \& IsuKa, M. (1964). Re-examination of some physiological characteristics of Xanthomonas oryzae (Uyeda et Ishiyama) Dowson. Annals of the Phytopathological Society of Japan 29, 13-19.

Muruta, N. \& Stark, M. P. (1973). A concept of the genus Xanthomonas and its species in the light of segmental homology of deoxyribonucleic acids. Phytopathologische Zeitschrift 77, 285-323.

OU, S. H. (1972). Rice Diseases. Kew, England: Commonwealth Mycological Institute.

Ou, S. H., Franck, G. P. Merca, S. D. (1971). Varietal resistance to bacterial leaf streak disease of rice. Philippine Agriculture 54, 8-32.

OWEN, R. J. \& JACKMAN, P. J. H. (1982). The similarities between Pseudomonas paucimobilis and allied bacteria derived from analysis of deoxyribonucleic acids and electrophoretic protein patterns. Journal of General Microbiology 128, 29452954.

ReckHuus, P. M. (1982). Occurrence of bacterial blight of rice in Niger, West Africa. Plant Disease 67, 1037.

ReDDY, C. R. \& OU, S. H. (1974). Differentiation of Xanthomonas translucens f. sp. oryzicola (Fang et al.) Bradbury, the leaf-streak pathogen, from Xanthomonas oryzae (Uyeda and Ishiyama) Dowson, the blight pathogen of rice, by enzymatic tests. International Journal of Systematic Bacteriology 24, 450-452.

REDDY, C. R. \& OU, S. H. (1976). Characterization of Xanthomonas oryzae (Uyeda et Ishiyama) Dowson, the bacterial blight pathogen of rice. Annals of the Phytopathological Society of Japan 42, 124-130.

Shekhuwat, G. S. Srivastava, D. N. (1968). Variability in Indian isolates of Xanthomonas oryzae (Uyeda and Ishiyama) Dowson, the incitant of bacterial leaf blight of rice. Annals of the Phytopathological Society of Japan 31, 289-297.

SKeruan, V. B. D., McGowan, V. \& SNeath, P. H. A. (editors) (1980). Approved lists of bacterial names. International Joumal of Systematic Bacteriology 30, 225-420.

SNEATH, P. H. A. SOKal, R. R. (1973). Numerical Taxonomy. The Principles and Practice of Numerical Classification. San Francisco: W. H. Freeman.

SOKAL, R. R. Michener, C. D. (1958). A statistical method for evaluating systematic relationships. University of Kansas Scientific Bulletin 38, 1409-1438.

STARR, M. P. (1945). The nutrition of phytopathogenic bacteria. I. Minimal nutritive requirements of the genus Xanthomonas. Journal of Bacteriology 51, 131 143.

Swings, J., Kersters, K. \& De LeY, J. (1976). Numerical analysis of electrophoretic protein patterns of Zymomonas strains. Journal of General Microbiology 93, 266-271.

Swings, J., Gillis, M., Kersters, K., De Vos, P., Gosselé, F. \& DE LEY, J. (1980). Frateuria: a new genus for Acetobacter aurantius. International Journal of Systematic Bacteriology 30, 547-556.

Swings, J., De Vos, P., Van den Mooter, M. \& De LEY, J. (1983). Transfer of Pseudomonas maltophilia Hugh 1981 to the genus Xanthomonas as Xanthomonas maltophilia (Hugh 1981) com. nov. International Journal of Systematic Bacteriology 33, 409413.

TsuchiYa, K., MEW, T. W. \& Wakmoto, S. (1982a). Bacteriological and pathological characteristics of wild types and induced mutants of Xanthomonas campestris pv. oryzae. Phytopathology 72, 43-46.

TsuchiYa, K., CHOI, J. E., MEW, T. W. \& WAkiMoto, S. $(1982 b)$. Serological properties of mutant strains of Xanthomonas campestris pv. oryzae induced by $N$ methyl- $N$-nitro- $N$-nitroso-guanidine. Annals of the Phytopashological Society of Japan 48, 9-18.

VAN LANDECHOOT, A. \& De LEY, J. (1983). Intra- and intergeneric similarities of the rRNA cistrons of Alteromonas, Marinomonas (gen. nov.) and some other Gram-negative bacteria. Journal of General Microbiology 129, 3057-3074.

W AKImOTO, S. (1960). Classification of strains of Xanthomonas oryzae on the basis of their susceptibility against bacteriophages. Annals of the Phytopathological Society of Japan 24, 193-198.

Watanabe, M. (1966). Studies on the strains of Xanthomonas oryzae (Uyeda et Ishiyama) Dowson, the causal bacterium of the bacterial leaf blight of rice plant. Bulletin of the Faculty of Agriculture, Tokyo University of Agricultural Technology 10, 1-51.

Wishart, D. (1978). Clustan User Mamual, Version IC, Release 2, 3rd edn. Edinburgh: Program Library Unit, Edinburgh University. 